\title{
RESEARCHPAPER
}

\section{Length weight relationship of Laubuka laubuca, Salmophasia phulo and Esomus danricus (Hamilton,1822) from lower Brahmaputra drainage of Assam, North-East India}

\author{
Department of Zoology, Gauhati University, Guwahati (Assam) India \\ Email : sarma_dandadhar@yahoo.com; ckalita30@gmail.com
}

Chandana Kalita and Dandadhar Sarma

Article Info : Received : 18.08.2018; Revised : 10.09.2018; Accepted : 21.09.2018

Length-weight relationships (LWRs) for three cyprinids (Laubuka laubuca, Salmostoma phulo and Esomus danricus) collected seasonally from May 2016 to January 2017 along the lower Brahmaputra drainage in Assam (Northeast India), using fishing gears [cast nets: $2.5 \mathrm{~m}, 10-15 \mathrm{~mm}$ mesh size; gillnets: $30 \times 0.9 \mathrm{~m}, 18-20 \mathrm{~mm}$ mesh size], were estimated. The ' $b$ ' values in the LWRs were 3.46 for L. laubuca, 2.98 for S. phulo and 3.13 for E. danricus, respectively.

Key words : Length weight, L. laubuca, S. phulo, E. danricus

How to cite this paper : Kalita, Chandana and Sarma, Dandadhar (2018). Length weight relationship of Laubuka laubuca, Salmophasia phulo and Esomus danricus (Hamilton,1822) from lower Brahmaputra Drainage of Assam, North-East India. Asian J. Bio. Sci., 13 (2) : 62-64.DOI : 10.15740/HAS/AJBS/13.2/62-64. Copyright@ 2018: Hind Agri-Horticultural Society. 